\title{
A symbiotic relationship between Lean Production and Ergonomics: insights from Industrial Engineering final year projects
}

\author{
Anabela Carvalho Alves \\ ALGORITMI Centre, Department of Production and Systems, School of Engineering, University of Minho, \\ Campus of Azurém, 4800-058 Guimarães, Portugal \\ anabela@dps.uminho.pt \\ Ana Cristina Ferreira \\ ALGORITMI Centre, Department of Production and Systems, School of Engineering, University of Minho, \\ Campus of Azurém, 4800-058 Guimarães, Portugal \\ acferreira@dps.uminho.pt \\ Laura Costa Maia \\ ALGORITMI Centre, Department of Production and Systems, School of Engineering, University of Minho, \\ Campus of Azurém, 4800-058 Guimarães, Portugal \\ lauracostamaia@gmail.com

\section{Celina P. Leão} \\ ALGORITMI Centre, Department of Production and Systems, School of Engineering, University of Minho, \\ Campus of Azurém, 4800-058 Guimarães, Portugal \\ cpl@dps.uminho.pt \\ Paula Carneiro \\ ALGORITMI Centre, Department of Production and Systems, School of Engineering, University of Minho, \\ Campus of Azurém, 4800-058 Guimarães, Portugal \\ pcarneiro@dps.uminho.pt
}

Received (8-MAR-2019); Revised (24-SEP-2019); Accepted (4-OCT-2019); Published online (8-OCT-2019)

\begin{abstract}
Lean production is an organisational management model that increases productivity by eliminating wastes (Muda), physical strain or overburden (Muri), and irregularity (Mura) (3M). These last two are related to the way people work, which is frequently harder instead of smarter. LP helps in achieving smart and effective methods of work. This paper aims to illustrate the synergy between LP and ergonomics by the analysis of a set of final year projects developed in the context of master's degrees dissertations of Industrial Engineering. It is intended to identify in these the symbiotic relationship between LP and ergonomics solutions that promotes smart, safe and effective work methods. Both share similar concerns about people welfare, providing not only tangible benefits but also intangible benefits. Several final year projects, reported in a set of master's degrees dissertations in Industrial Engineering, were used to explore if and which ergonomic factors were considered in lean projects developed, by final-year engineering graduates, in an industrial environment. The project phase in which this aspect was manifested and the benefits that resulted from these projects were also studied. The analysis and interpretation of the dissertations showed that, even when the work plan for the project did not reflect the study or evaluation of the workers' conditions in the lean projects, in most cases, this kind of study was performed to provide solutions for reducing the 3M. A lean project implementation only makes sense when people are respected and their work conditions are considered satisfactory. When this is assured, LP and ergonomics contribute to the improvement of the company productivity, moreover when relevant ergonomic aspects are considered in the work proposal planning phase of the leanrelated projects.
\end{abstract}

Key words: Ergonomics; Industrial environment; Lean production; Working conditions 


\section{INTRODUCTION}

Considering the market demands, companies must satisfy their customers in a faithfully and sustainable way. Customers need to feel that they are paying the right price for the right quality products, without being charged for costs in activities they do not want to pay for. To achieve this, the Lean Production (LP) organisation model, propagated by Womack et al. [1], has been implemented by many companies in all over the world [2-4]. Bhamu and Sangwan [2] in their review have compiled more than 40 works of LP implementation in several industrial contexts (e.g. construction, shipbuilding, telecommunications, food, automotive, aircraft, electronics, precision materials, etc.) spread worldwide (e.g. Australia, China, France, India, Italy, Japan, Norway, Sweden, United Kingdom and United States of America among others). Additionally, Amaro et al. [4] reviewed 129 case studies and surveys of LP implementation in the last 25 years. These case studies were from the industry sector (discrete and process manufacturing) to the services sector (e.g. healthcare,...) among others and were spread from more than 14 countries. In common, these works show the implementation of tools and techniques applied to all functional areas to eliminate waste, improve productivity and promote innovation. Furthermore, Amaro et al. [4] presented the benefits of Lean, highlighting the effects of wastes reduction on the environmental positive results.

LP was the designation used by John Krafcik [5], an MIT International Motor Vehicle Program (IMVP) researcher, to name the existing Toyota Production System (TPS) [6, 7], which emerged in the post-second World War during difficult times for all but particularly for Japan. TPS benefited from mass production knowledge and practices such as standardisation and mixed this with other equally important components forgotten in Ford system: minds and hands of workers, working together in teams to achieve higher performance [5]. Though classical principles such as the ones from scientific management of Taylor, and others were very important to higher human performance, some changes were needed to integrate the human element and improve human-system performance [8].

Like other initiatives [8], TPS development had this in consideration. Sugimori et al. [9], in a paper that was probably the first in English about TPS, called it a "respect-for-human system" because of its emphasis on three aspects: i) elimination of waste movements by workers; ii) consideration for workers' safety; and iii) selfdisplay of workers' capabilities by entrusting them with greater responsibility and authority.

Nevertheless, LP impact on human relations and working conditions is controversial due to many reasons, being one of them the misunderstanding of lean principles [10]. However, LP is nowadays recognized as a socio-technical system [11] and a business strategy [12] or even a philosophy [13] that allied with other disciplines, namely, ergonomics, form a strategic alliance to achieve the purpose and objectives of each one of them. Ergonomics, as applied science, will better achieve the health and safety objectives in cooperation with a business strategy like LP [12].

In this paper, a quantitative and qualitative content analysis was conducted to illustrate the symbiotic relationship between LP and ergonomics, which emerges even when not initially planned for lean-related projects. These documents correspond to a set of master's dissertations in Industrial Engineering that resulted from final projects; all of them developed in an industrial environment at several companies. The study identifies the phase at which the ergonomics factors were included, as well as the achieved benefits.

This paper is organised into five sections. The first one introduces the most important concepts of LP and Ergonomics and states study objectives. The second section presents a brief literature review to LP, ergonomics and the relationship between these two concepts. The third section presents the methodology followed. The fourth section explores the contents of the master's dissertations, discussing the main results of them. This paper ends with the conclusions and limitations of the study.

\section{LITERATURE REVIEW}

This section introduces briefly the Lean Production roots, definitions and principles. Also, defines ergonomics and their importance to workers. Finally, the section ends with the evidences of the relationship between lean and ergonomics.

\subsection{Lean Production}

After World War II, the Japanese manufacturers faced a great dilemma regarding lack of material, economic, and human resources, in contrast to the required variety of production. Kiichiro Toyoda, Taiichi Ohno, and others at Toyota analysed this situation and thought that a series of simple innovations could provide continuity of the process flow and a wide variety of product offerings [14]. Therefore, they revisited Ford's original philosophical principles and created the TPS [15, 16]. This production system, known today as "lean production", was based on the minimisation of resources consumption and the addition of value to a product. It was also based on the recognition that only a small fraction of the total time and effort of a process added value to the end customer [17]. As explained in the book "The Machine That Changed the World" [1], a movement from mass production towards lean manufacturing occurred when the companies realised the great success of Toyota, which, at the time, developed, produced, and distributed products with half of the capital investment, infrastructures, materials, time, and even human effort $[1,16]$. The term "lean" is linked to the key idea of "doing more with less". According to Womack et al. [1], that means a system that requires less general inputs to create the same outputs as those created by a traditional mass production system, while reducing the costs through continuous improvement and, thus, increasing the profits [18]. A misunderstanding of this key idea could conduce to the misconception of what is LP and partial 
implementations of it, resulting in a more stressful environment than the previous system implemented and fear of job loss $[10,19]$. The main consequence is a suspicious about LP that is often seen by various authors as a production system that does not care about people; however, this is controversial [10]. Furthermore, people in both the industrial and academic field express some reservations about the lean methodology [10]. In fact, lean's main objective - reduction of waste, could be associated with dismissals or even reduction of human resources. This association is clearly a wrong line of thinking and, thus, it is of utmost importance to understand the full meaning of lean methodology, which is preserving jobs whenever possible [19]. Nevertheless, the lean approach is extended beyond automotive production to any company or organisation, in any sector in any country $[3,4]$.

The Lean Thinking can be divided into five principles (Figure 1) that represent its essence: i) Value: specify what does and does not create value from the customer's perspective instead of from the perspectives of individual firms, functions, and departments; ii) Value Stream: identify all the steps necessary to design, order, and produce the product across the whole value stream to highlight non-value-adding waste; iii) Flow: implement actions that create value flow without interruption, backflows, waiting, or reworks; iv) Pull production: produce only what is required by the customer; and, finally, (5) Pursuit Perfection: strive for perfection by continually removing successive layers of waste as they are uncovered $[18,20]$.

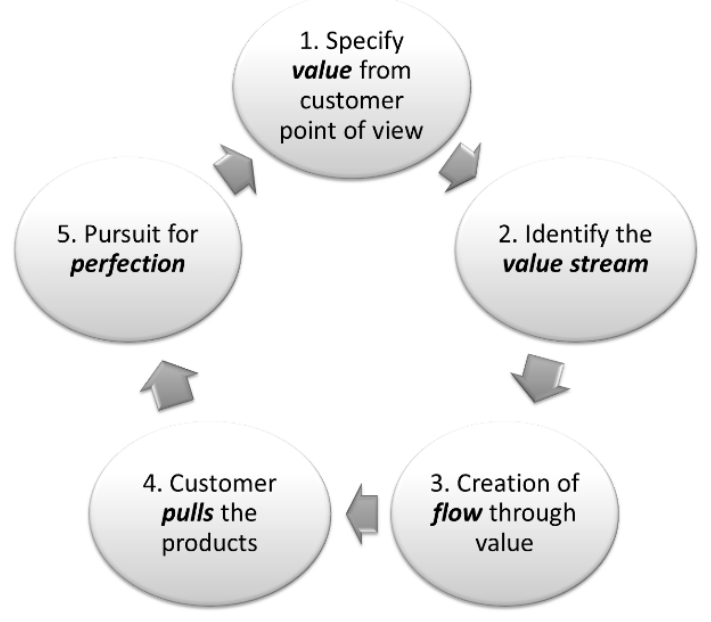

Figure 1. Schematics of the application of Lean principles.

\subsection{Ergonomics}

According to the International Ergonomics Association [21], "Ergonomics (or human factors) is concerned with the understanding of interactions among humans and other elements of a system, in order to optimise human wellbeing and overall system performance". Thus, ergonomics contemplates both the physical and psychological human aspect and involves looking for solutions in both the technical and organisational domain [18, 21, 22].

The analysis of work systems is imperative for a better allocation of functions and technical equipment to the workers. This analysis will assist in making informed decisions to enhance the work safety, productivity, and the wellbeing of workers.

Checklists and questionnaires are common tools for gathering information about ergonomic aspects. According to David [23], a questionnaire is an efficient method for collecting a large amount of information in short periods of time. In an ergonomic checklist, a list of ergonomic factors is presented, and the observer only has to answer "Yes" or "No" to each of them. It is also possible to write remarks for each factor. These methods allow users to have an overview of the ergonomic aspects of the work system. Checklists highlight the aspects that need urgent intervention and can also allow prioritising action plans.

Many methods have been proposed over the last 30 years for the systematic and comprehensive assessment of a workstation [24]. Most of them are based on observational techniques, applying a specific posture classification: Ovako Working Posture Assessment System (OWAS), Posture, Activity, Tools and Handling (PATH), Quick Exposure Check (QEC), Rapid Upper Limb Assessment (RULA), Strain Index (SI), Occupational Repetitive Actions (OCRA), NIOSH Lifting Equation, Rapid Entire Body Assessment (REBA), Ergonomic Workplace Analysis (EWA), among others [25, 26]. EWA is a largely used method because its structure is suitable for most industrial activities, allowing a more complete analysis of the relationship between the workstation considerations and the worker posture and physical effort [27]. Besides that, as EWA is an observational method, it implies low cost, noninterference with the job process, and ease of application [25]. EWA was developed by the Finnish Institute of Occupational Health $(\mathrm{FIOH})$ [28] and is a semi-quantitative method that allows a wide ergonomic analysis covering fourteen ergonomic factors. The observer assigns to each point a classification on a scale of either four or five. A score of 5 indicates a risky situation for the worker's health. In contrast, a score of 1 indicates safe working conditions. The workers also evaluate the same aspects of the workstation in a qualitative way (very good (1), good (2), poor (3) and very poor (4)).

Additionally, Shoaf et al. [29] developed a set of mathematical models for manual lowering, pushing, pulling and carrying activities by establishing load capacity limits to protect the lower back against occupational low-back disorders.

\subsection{Evidence of the relationship between LP and Ergonomics}

Successful LP implementation involves more than process improvement. Any change in work practices has effects on workers and their performance, which should be assessed [30]. Those effects include not only the commitment of the workers to the new practices but also the concern for their wellbeing, safety, and security. Aligned with this perspective, several authors defend the thesis that human factors (i.e. ergonomics) can help a company's business strategy to stay competitive [31]. 
According to Genaidy and Karwowsky [32], one must look deeper into the impact that lean production strategies have on the work demand and energizer profiles, and worker health to chart the best human performance practices required to achieve and sustain work productivity, quality, and safety. These authors highlight that the worker is at the heart of application of the lean production model.

According to Brito et al. [33], ergonomics should be integrated into the lean process from the planning phase, which unfortunately does not occur in many companies. In fact, when decisions about products or processes are made, most resources are already assigned so that the cost of any modification rises acutely. The industrial projects implementing LP do not always address the ergonomics factors [34]. Most of the projects are only focused on the benefits of productivity and process pointof-view [35]. As a consequence, the benefits regarding human factors are not very significant [36].

As Guimarães et al. [37] argue, ergonomics and safety must be considered in the lean-related projects to design, improve and test the production system, identifying workers' best conditions. Ergonomic metrics must be included in the lean-related projects to evaluate how lean "improvements" may affect, for example, musculoskeletal disorder (MSD) risk factors associated with the job or jobs that were changed [37].

When talking about the inclusion of ergonomics into the lean-related projects, a more complete analysis has to be performed and additional factors accounted; one of them regards lean prioritisation. The use of Value Stream Mapping (VSM), root-cause analysis, Ishikawa diagram and other methods to visualise the companies' operations allows selecting work activities or production processes to perform a lean analysis [38]. Incorporating workplace design-related risk assessment and implementing quality metrics into the value stream mapping process, provides a structured method for prioritising lean opportunities, the application of scored risk assessments, and the identification of work design flaws. Thus, the quality metrics/ risk factor assessment integration can be used as additional data for lean manufacturing interventions [39].

According to Losonci et al. [40], the ergonomic concepts and ergonomic design factors should be included in the training of lean team members so they can recognise risk factors and apply these ergonomic design options as they develop conceptual designs. Lean team members may perform risk assessments about the worker health and safety, by evaluating how workers interact with workstations, materials and tools. In fact, training is critical to ensure that team members are well-informed and comfortable with these tasks [40]. Applying ergonomic design concepts will reduce costly errors, improve productivity, and reduce MSD risk factors that lead to higher workers' compensation costs. Ergonomic design goals focus on creating efficient and appropriate body postures, reducing the amount of strength required to complete a task, and avoiding repetitive postures and motions throughout the work shift. For instance, applying force takes time, increases the risk of strains and other injuries, and causes employees to fatigue - which slows their work pace and reduces their productivity. These consequences are called Muri, which is a symptom of waste in lean language, as well as Mura or irregularity. When it is present, Mura can lead to accidents, time loss, confusion, etc. Clearly, the goals of the ergonomic design complement the goals of the lean process and can mitigate the risk created by some lean solutions.

Many MSD risk assessment tools present the risk level through a score, enabling the lean team to compare the level of risk presented by various production processes. Since the presence of MSD risk factors is a leading indicator of high incidence rates and higher workers' compensation costs, the risk factor scores provide objective data that can be used to identify potential ergonomic and productivity issues. Many companies use these risk assessment methods before and after implementing new lean workflow and workstation designs. These assessments enable lean teams to confirm whether the changes have a positive impact on the level of risk and to identify unintended consequences of the new design that may lead to increased MSD risk.

Involving all the users of the process to be redesigned (hourly employees, supervisors, maintenance, etc.) is critical to the success of any lean intervention. These stakeholders understand problems related to the workflow, issues with incoming parts and equipment, and variances in production scheduling that may not be understood by an external lean team. Thus, the lean team needs to collaborate closely with these stakeholders to capture these issues and production variances, to ensure that the new lean design is adaptable and efficient. The hourly employees typically provide some of the best design ideas, so it is essential to get them involved in the discussion [41, 42]. Furthermore, it should be noted that the employees might not use new tooling if they are not involved in the selection and installation of the equipment. Many manufacturers have invested in state-of-the-art material handling equipment only to find that employees choose to lift the product rather than using the equipment selected by the management. Stakeholder involvement is crucial for the acceptance and effective implementation of lean design modifications [31].

Measuring the financial impact of lean and ergonomic integration solutions is essential to obtain continued support and involvement from senior management. Frequently updating the management on the cost savings in productivity, quality, and workers' compensation claims will ensure that the process continues to be a management priority [31].

Workers' compensation costs should include the total cost of claims related to the workspace and the lean initiative measures. The costs of injuries and workers' losses can be reduced, and labour productivity can be increased if the workers' compensation is quantified considering the insurance and the internal risk by the management department [31]. Productivity gains can be translated into cost reductions by multiplying the cost of 
labour by the calculated reduction in man-hours. Quality savings can be estimated based on the current cost of returns, rework, and warranties. The reduction of workers' compensation cost can be based on current claim costs and on the reduction in MSD risk factor scores. Thus, the estimation of conservative cost savings ensures that resources will continue to be provided for the lean process [43]. LP implementations have a positive impact on ergonomics initiatives as shown by many examples published elsewhere [44-47].

\section{RESEARCH METHODOLOGY}

The systemization of information relevant to the objective of the present paper was based on quantitative and qualitative content analysis. The sample considered in the study was based on a set of 41 lean-related projects in the fields of Production Systems Design and Operation; LP, and Logistics. These projects were developed in the context of master's dissertations carried out during 2008-2015 by students of a master's degree in Industrial Engineering and an integrated master's degree in Industrial Engineering and Management. This sample was chosen because it was considered representative for this study. These master's theses correspond to the final output of industrial training programs. These real-world experiences create opportunities to prepare graduate engineering students for the challenges ahead. The 41 lean-related projects considered in the analysis were all supervised by one of the co-authors of this paper. Thus, the supervisor's perception within the training visits to the company's facilities was also an important contribution to the interpretation and discussion. From the methodological point-of-view, the content of text data of the master dissertations set was analysed, involving counting and comparisons of predefined keywords, followed by the corresponding interpretation [48]. The quantification of keywords in data can present insights on the use and on the context, helping to identify some similarities or differences. The outcomes of the analysis were reported by descriptive summaries and presented in tables and graphs with the frequencies of each of the identified ergonomic factors and used lean tools and its combination. The variables code for each master's dissertation corresponded to each of the identified lean tools and ergonomic factors described in the corresponding engineering students' work.

The ergonomic factors collected from the master's dissertations were classified within the fourteen categories addressed and assessed as an ergonomic factor by EWA. The fourteen categories of ergonomic factors and a brief description of each one are given in Table 1. Besides the obtained descriptive database on the fourteen ergonomic factors, the analysis also allowed to find relevant information that otherwise could not have been directly identified. When analysing the lean-related projects, each identified ergonomic factor was categorized according to the meaning of the principle.

The objectives of the analyses and discussions were: $i)$ to verify if ergonomics was a concern in lean-related projects and, if so, in which phase of the project was this identified; ii) to synthesise which ergonomic factors were considered in these lean-related projects and with which lean tools; and iii) to identify the main benefits attained by such integration.

Table 1. Description of the fourteen ergonomic factors of EWA method.

\begin{tabular}{|c|c|}
\hline Ergonomic factor & Factor description \\
\hline F1 - Worksite & $\begin{array}{l}\text { Assessment of the workplace height, horizontal working area, distance and angle of } \\
\text { vision, legs space, seat, hand tools, and other equipment. }\end{array}$ \\
\hline F2 - General physical activity & $\begin{array}{l}\text { Assessment of the level of physical activity required for the job and whether the } \\
\text { worker can regulate the physical load. }\end{array}$ \\
\hline F3 - Lifting tasks & $\begin{array}{l}\text { Verification of the height at which the lifting is made, the weight of the load, and the } \\
\text { horizontal distance of handholds. }\end{array}$ \\
\hline F4 - Postures and movements & $\begin{array}{l}\text { Assessment of the working postures/movements for different parts of the body, } \\
\text { namely neck-shoulders, elbows-wrists, the back, and hips-legs. }\end{array}$ \\
\hline F5 - Accident risk & Assessment of the likelihood of accidents and their severity. \\
\hline F6 - Job contents & Number and quality of the individual tasks included in the working activity. \\
\hline F7 - Job restrictiveness & Identification of situations that can possibly limit the activity of the workers. \\
\hline F8 - Communication and personal contacts & Opportunities that workers have to communicate with their peers and/or superiors. \\
\hline F9 - Decision-making & $\begin{array}{l}\text { Verification of the degree of information availability, as well as the underlying } \\
\text { decision risk. }\end{array}$ \\
\hline F10 - Repetitiveness of the work & Average duration of a repetitive work cycle. \\
\hline F11 - Attention & Relationship between the duration of observations and the required level of attention. \\
\hline F12 - Lighting conditions & $\begin{array}{l}\text { Measurement of illumination in the working area and corresponding calculation of the } \\
\text { ratio: (measured value/recommended value) } \times 100 \text {. It also includes brightness. }\end{array}$ \\
\hline F13 - Thermal environment & Measurement of the temperature, relative humidity, and air velocity. \\
\hline F14 - Noise & $\begin{array}{l}\text { Measurement of the noise level in the workplace, according to the type of work } \\
\text { developed. }\end{array}$ \\
\hline
\end{tabular}


In order to accomplish the objectives, research questions and sub-questions were proposed. Those are described below and presented in Table 2. The first research question (RQ1) was aimed to identify if and describe which ergonomic factors (sQR11) were considered during the lean-related project development, and in which phase were these factors considered (sQR12). By phase of lean-related project development, the authors mean the identification of the moment when the ergonomic concerns arise, i.e., if in the definition of objectives of the work plan proposal, in its initiation and execution, or at project completion.

An additional sub-question (sQR13) was created to understand with which implemented lean tools were the ergonomic factors addressed. The second research question (RQ2) was aimed to identify the ergonomic benefits brought by lean tools (sQR21) and, consequently, understand if they were easily identified (sQR21).

An interpretative analysis of the contents was carried out to understand the words and answers to the research questions. Finally, the main conclusions were pointed out.

Table 2. Research questions (RQ) and sub-questions (sQR) considered in the research

\begin{tabular}{l|l}
\hline $\mathbf{R Q}$ & $\mathbf{S Q R}$ \\
\hline
\end{tabular}

SQR11: Which ergonomic factors were considered during the lean methodology implementation?

SQR12: In which phase of the lean project were ergonomic factors considered?

sQR13: With which lean tools were ergonomic factors revealed and addressed?

SQR21: What were the benefits of integrating ergonomic factors in an LP methodology?

sQR22: Were they easily identified by the project authors?

\section{RESULTS AND DISCUSSION}

The results presentation and corresponding discussion are presented. Firstly, the projects are characterized, and, then, questions raised in the research methodology section are answered in each of the following subsections.

\subsection{Characterisation of the projects}

In this paper, 41 final-year projects on lean, performed in the context of master's dissertations, were analysed. These projects had been developed in 29 different companies between 2008 and 2015. The projects were classified as "P\#" (P1 to P41) and the companies as "C\#" (C1 to C29).
Table 3 presents the characterisation of the projects indicating the company (Comp.), the year, the type of company, and the main objective of each project. Most companies were automotive industry suppliers of car radios and navigation systems, metal parts, electronic parts, and textile parts.

During the study period (2008-2015), the number of projects by year was variable. The number of projects by company was usually one but four companies had more than one. For instance, in the same year, seven projects were developed in $\mathrm{C} 1$ while three were accepted in $\mathrm{C} 5$. It should be noted that $\mathrm{C} 1$ is an international company of electronic components for the automotive industry with a long journey of LP implementation.

\subsection{Ergonomic factors in the lean-related projects}

The fourteen ergonomic factors mentioned in the research methodology section were considered for the analysed projects. The ergonomic factors present in the different projects are indicated in Table 4 (cells in grey), where the projects were grouped by company. "C\#" represents the company number and the numbers in brackets "(\#/\#)" represent the number of projects that considered ergonomic factors in each company. The table only shows the projects where ergonomic factors were identified (32 of 41 projects in 24 of the 29 companies of the study). This table also reveals the total. The factors (columns) are organised from the most to the least referred.

The last column " $\Sigma$ " shows the number of factors identified in the projects, and the last line shows how many times the factor was referred. The analysis and identification of ergonomic factors in the master's dissertations became a difficult task and had some limitations. It was found that the students did not always identify directly the ergonomic factors, i.e., sometimes these factors were identified as tools for improving productivity and motivation and reducing absenteeism. The fact that projects did not present any ergonomic factor did not necessarily mean that these were not included since it could have been caused by a misinterpretation or disregard by the student. For instance, in P20 the F4 was only identified in a dissertation annex and was considered after an additional assessment that was not associated with other data, neither referred in the final conclusions.

From the 29 companies of the study, 24 had projects where ergonomic factors were considered. The fact that some companies were not identified (C22, C25, C27, $\mathrm{C} 28$, and C29) does not mean that they were not aware or concerned with working conditions. For instance, C25 and C29 are companies that promote better work conditions, even though the project did not approach these. This study was the first project on companies of this type conducted by the co-authors. C22 is an administrative service in the educational sector, so its project (P33) was developed in a lean office context [3]. Additionally, C28 is an industrial company, but its project (P40) was also developed in a lean office context corresponding to the administrative sector, and the 
ergonomic aspects were not approached. In C1, only two of the projects did not consider ergonomic factors, because they were more related to suppliers logistic. The same occurred with P6 developed in C3, P28 in C5, and P39 in C27.

Table 4 reveals that the ergonomic factors most identified in the projects were "worksite" (F1) and "postures and movements" (F4). In fact, the most common tools applied in most of the project include 5S, visual management and standard work implementation which directly affects the working conditions, the workplace itself and, therefore, the postures, the type and amount of movements of the workers in their daily activities.

Table 3. Characterisation of the final-year projects on lean

\begin{tabular}{|c|c|c|c|c|}
\hline Comp. & Project & Year & Type & Main objectives \\
\hline C1 & $\begin{array}{l}\text { P1 } \\
\text { P3 } \\
\text { P4 } \\
\text { P10 P13 } \\
\text { P19 P36 }\end{array}$ & $\begin{array}{l}2008 \\
2008 \\
2009 \\
2011 \\
2011 \\
2012 \\
2015\end{array}$ & $\begin{array}{l}\text { Electronic components for } \\
\text { the automotive industry }\end{array}$ & $\begin{array}{l}\text { Increase of cells productivity; } \\
\text { Levelling implementation; } \\
\text { Improvement of cells teamwork performance; } \\
\text { Pull system implementation; } \\
\text { Value stream flow optimisation; } \\
\text { Kanban implementation with suppliers; } \\
\text { Improvement of logistics in materials reception. }\end{array}$ \\
\hline $\mathbf{C 2}$ & P2 & 2008 & Water heaters & Reconfiguration of production systems. \\
\hline C3 & $\begin{array}{l}\text { P5 } \\
\text { P6 }\end{array}$ & $\begin{array}{l}2009 \\
2009\end{array}$ & $\begin{array}{l}\text { Metal components for the } \\
\text { automotive industry }\end{array}$ & $\begin{array}{l}\text { Lean manufacturing application - expedition; } \\
\text { Lean manufacturing application in logistics. }\end{array}$ \\
\hline C4 & P7 & 2010 & $\begin{array}{l}\text { Metal mechanics for } \\
\text { construction }\end{array}$ & Practices application of Lean manufacturing. \\
\hline C5 & $\begin{array}{l}\text { P8 } \\
\text { P15 } \\
\text { P22 } \\
\text { P28 } \\
\text { P29 }\end{array}$ & $\begin{array}{l}2010 \\
2012 \\
2013 \\
2013 \\
2013\end{array}$ & Electric devices (appliances) & $\begin{array}{l}\text { Assembly cells implementation for product } \mathrm{X} \text {; } \\
\text { Assembly cells implementation for product } \mathrm{Y} \text {; } \\
\text { Lean manufacturing application in metal; } \\
\text { Internal logistic streams improvement; } \\
\text { External logistic reorganisation. }\end{array}$ \\
\hline C6 & P9 & 2011 & Garment & Lean and cellular implementation. \\
\hline $\mathbf{C 7}$ & P11 & 2011 & Hospital & Lean healthcare application. \\
\hline C8 & $\mathrm{P} 12$ & 2011 & Luxury beds & Lean thinking principles application. \\
\hline C9 & P14 & 2011 & Plastic & Lean manufacturing tools application. \\
\hline C10 & P16 & 2012 & Elevators & Application of standard work and other lean tools. \\
\hline C11 & $\mathrm{P} 17$ & 2012 & Automotive components & LP tools implementation in the finishing sector. \\
\hline C12 & $\begin{array}{l}\text { P18 } \\
\text { P32 }\end{array}$ & $\begin{array}{l}2012 \\
2014\end{array}$ & Furniture & $\begin{array}{l}\text { Standard work in a paint section; } \\
\text { Standard work in panel production. }\end{array}$ \\
\hline C13 & $\mathrm{P} 20$ & 2012 & Shoes & Lean production implementation. \\
\hline C14 & $\mathrm{P} 21$ & 2013 & Automotive components & $\begin{array}{l}\text { Management, balancing, and formation of sewing cell } \\
\text { teams. }\end{array}$ \\
\hline C15 & P23 & 2013 & Cutlery & Lean production implementation. \\
\hline C16 & P24 & 2013 & Metal mechanics & Cellular production and Lean tools in warehouses. \\
\hline C17 & P25 & 2013 & Refrigerator & Lean and cellular production implementation. \\
\hline C18 & P26 & 2013 & Machine-tools & Application of standard work and other lean tools. \\
\hline C19 & $\mathrm{P} 27$ & 2013 & Electric devices & $\begin{array}{l}\text { Reconfiguration of a traditional production system in a } \\
\text { lean production system. }\end{array}$ \\
\hline $\mathbf{C 2 0}$ & P30 & 2013 & Automotive components & Lean production tools implementation. \\
\hline C21 & P31 & 2014 & Garment & Lean production tools implementation. \\
\hline C22 & P33 & 2014 & University academic services & Lean services tools application. \\
\hline $\mathbf{C 2 3}$ & P34 & 2014 & Logistic transports & Lean logistic application. \\
\hline $\mathrm{C24}$ & P35 & 2014 & Office products & Lean and cellular production implementation. \\
\hline $\mathbf{C 2 5}$ & P37 & 2015 & Wiring systems & Lean production tools implementation. \\
\hline $\mathrm{C} 26$ & P38 & 2015 & Automotive components & $\begin{array}{l}\text { Performance improvement of an assembly final section } \\
\text { using lean tools. }\end{array}$ \\
\hline $\mathbf{C 2 7}$ & P39 & 2015 & Copy machines distribution & Lean tools implementation to improve logistics processes. \\
\hline $\mathrm{C} 28$ & $\mathrm{P} 40$ & 2015 & $\begin{array}{l}\text { Automotive textile } \\
\text { components }\end{array}$ & $\begin{array}{l}\text { Improvement and standardisation of production tools } \\
\text { support applying lean tools. }\end{array}$ \\
\hline C29 & P41 & 2015 & Power transformers & Assembly time reduction of transformers using lean tools. \\
\hline
\end{tabular}


Table 4. Ergonomic factors presented in the different projects

\begin{tabular}{|c|c|c|c|c|c|c|c|c|c|c|c|c|c|c|c|c|}
\hline $\mathrm{C \#}(\# / \#)$ & $P \times F$ & $\mathrm{~F} 1$ & $\mathrm{~F} 4$ & $\mathrm{~F} 2$ & F8 & F3 & F5 & F10 & F6 & F9 & F7 & F13 & $\mathrm{F} 11$ & $\mathrm{~F} 12$ & $\mathrm{~F} 14$ & $\Sigma$ \\
\hline & P1 & & & & & & & & & & & & & & & 4 \\
\hline & P3 & & & & & & & & & & & & & & & 3 \\
\hline & P4 & & & & & & & & & & & & & & & 3 \\
\hline & P10 & & & & & & & & & & & & & & & 1 \\
\hline & P36 & & & & & & & & & & & & & & & 1 \\
\hline C2 (1/1) & P2 & & & & & & & & & & & & & & & 3 \\
\hline C3 (1/2) & P5 & & & & & & & & & & & & & & & 3 \\
\hline \multirow[t]{5}{*}{ C4 (1/1) } & P7 & & & & & & & & & & & & & & & 3 \\
\hline & P8 & & & & & & & & & & & & & & & 4 \\
\hline & P15 & & & & & & & & & & & & & & & 6 \\
\hline & P22 & & & & & & & & & & & & & & & 4 \\
\hline & P29 & & & & & & & & & & & & & & & 4 \\
\hline C6 (1/1) & P9 & & & & & & & & & & & & & & & 2 \\
\hline C7 (1/1) & P11 & & & & & & & & & & & & & & & 2 \\
\hline C8 (1/1) & P12 & & & & & & & & & & & & & & & 4 \\
\hline C9 (1/1) & P14 & & & & & & & & & & & & & & & 2 \\
\hline C10 (1/1) & P16 & & & & & & & & & & & & & & & 6 \\
\hline C11 (1/1) & P17 & & & & & & & & & & & & & & & 4 \\
\hline C13 (1/1) & P20 & & & & & & & & & & & & & & & 3 \\
\hline \multirow[t]{2}{*}{ C12 (2/2) } & P18 & & & & & & & & & & & & & & & 4 \\
\hline & P32 & & & & & & & & & & & & & & & 3 \\
\hline C14 (1/1) & P21 & & & & & & & & & & & & & & & 2 \\
\hline C15 (1/1) & P23 & & & & & & & & & & & & & & & 2 \\
\hline C16 (1/1) & P24 & & & & & & & & & & & & & & & 1 \\
\hline C17 (1/1) & P25 & & & & & & & & & & & & & & & 2 \\
\hline C18 (1/1) & P26 & & & & & & & & & & & & & & & 1 \\
\hline C19 (1/1) & P27 & & & & & & & & & & & & & & & 2 \\
\hline C20 (1/1) & P30 & & & & & & & & & & & & & & & 2 \\
\hline C21 (1/1) & P31 & & & & & & & & & & & & & & & 3 \\
\hline C23 (1/1) & P34 & & & & & & & & & & & & & & & 3 \\
\hline C24 (1/1) & P35 & & & & & & & & & & & & & & & 1 \\
\hline C26 (1/1) & P38 & & & & & & & & & & & & & & & 1 \\
\hline $24(32 / 36)$ & $\Sigma$ & 21 & 15 & 10 & 10 & 9 & 6 & 5 & 3 & 3 & 2 & 2 & 1 & 1 & 1 & 89 \\
\hline
\end{tabular}

The least identified factors were "attention" (F11), "lighting conditions" (F12), and "noise" (F14), which were all only considered once. Considering these last ergonomic factors, $\mathrm{F} 12$ and $\mathrm{F} 14$ can be considered relatively easy to measure (with appropriate measure devices), assess, and posteriorly identify, while F11 is difficult to measure. This ergonomic factors, F12 and F14 are aspects usually related to the type of activities developed in a specific industrial context and are defined when the facilities are projected.

The projects where the highest number of ergonomic factors was identified were P15 and P16, with six factors in each one. P15 was a project developed in an electronic appliances multinational company. After a first successful project that had been developed two years earlier, based on the reconfiguration of five assembly lines into two assembly cells, the company was so satisfied with the results that decided to reconfigure other assembly lines of a different product into assembly cells. The advantages of reconfiguring assembly lines into cells are well documented in the literature, showing the importance of this reconfiguration for waste elimination but also for ergonomic advantages [10, 49-51]. P16 was a project developed in an elevators company that was very motivated with its lean journey initiated by a consulting company. Results of the project developed by this company can be seen elsewhere $[52,53]$. 


\subsection{Phase of the lean-related project where ergonomic factors were considered}

The number of lean projects which included the ergonomic aspects in their objectives was assessed, in order to answer the research question "In which phase of the lean-related project was the ergonomic factors considered?" (sQR12). Three main levels were identified, as presented in Figure 2.

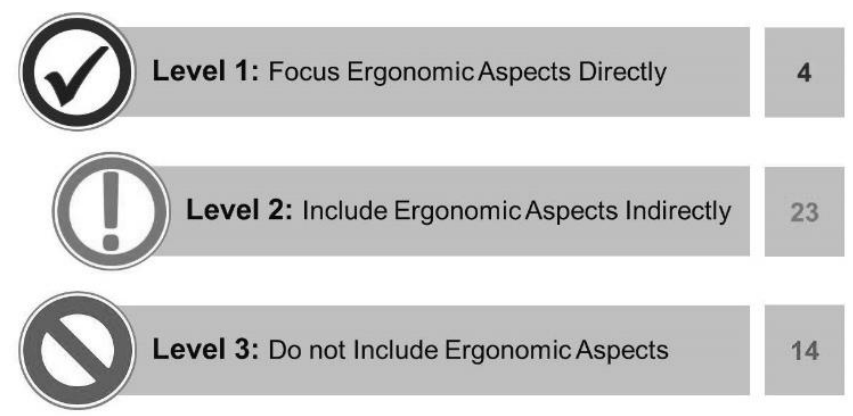

Figure 2. Number of lean-related projects that account the ergonomic factors in their objectives definition.

The first level corresponds to projects that focused directly on ergonomic aspects using specific keywords such as "workplace", "ergonomics", and "working conditions". The second level corresponds to projects that did not identify the improvement of ergonomic conditions as one of its objectives but included a set of measures that indirectly improved the workers' conditions. Keywords and expressions such as "movement reduction", "balanced manual load", "workers' productivity", and "musculoskeletal wear" were considered. The third level concerns projects that did not mention any of these aspects in their objectives definition and are thus categorised as projects that did not include ergonomic aspects in their initial phase.

According to Figure 2, 9.8\% of the studied lean-related projects mentioned directly ergonomic aspects improvement as an initial objective in the project development. Despite this low value, a deeper analysis was conducted in order to evaluate how the ergonomic aspects were included in the project plan. Table 5 presents the analysis of the four projects that directly included ergonomic improvement as an objective of the lean-related project implementation. The data shows that the implemented approaches from LP strategies, for example, the layout reorganization, the implementation of $5 \mathrm{~S}$ and manufacturing cells, the visual management, the production line balancing and others, allows measuring several aspects that both have impact in companies productivity and ergonomic welfare. The analysis also indicated that $56.1 \%$ of the lean projects comprised the improvement of either ergonomic or workplace conditions by applying lean tools. In some projects, although ergonomic aspects were integrated, they were not a concern when the projects were defined in a work plan proposal, but instead were considered later during the work implementation. This situation occurred because, most of the time, the problem/project was defined by company management. Even so, ergonomic aspects were naturally considered when the supervisor asked about the causes of the problems and the student needed to identify them. For example, some of the problems were lack of organisation at the workplace, too much time spent searching tools or materials, wrongly dimensioned supermarkets, too many errors, too many transports, too many movements, and lack of communication. To understand the causes of these problems, ergonomic factors needed to be assessed, such as worksite (F1), general physical activity (F2), lifting tasks (F3), postures and movements (F4), communication and personal contacts (F8). For example, in the case of P16, P25, P31, and P36 these problems and causes were assessed by ergonomic tools such as REBA, NIOSH lifting equation, EWA, and other tools used in this context: work-study, process analysis chart, and sequence chart $[47,52-55]$.

Table 5. Lean tools versus ergonomic factors of lean-related projects

\begin{tabular}{|c|c|c|c|}
\hline Projects & Objective & Approach & What was measured? \\
\hline P2 & $\begin{array}{l}\text { Propose an "ergonomic" } \\
\text { analysis of the } \\
\text { production system }\end{array}$ & $\begin{array}{l}\text { - Application of } 5 S \text { to the workplaces; } \\
\text { - Implementation of manufacturing cells; } \\
\text { - Standard Work } \\
\text { - Definition of good practices for the use } \\
\text { of consumables supermarkets; } \\
\text { - Adaptation of the production lines } \\
\text { dimensions. }\end{array}$ & $\begin{array}{l}\text { - Workers satisfaction through the } \\
\text { application of surveys about: } \\
\text { i) Movements and physical effort; } \\
\text { ii) Organization of the workplace; } \\
\text { iii) Access the information to do the } \\
\text { work. }\end{array}$ \\
\hline P21 & $\begin{array}{l}\text { Propose continuous } \\
\text { improvement of the work } \\
\text { environment and } \\
\text { "ergonomic conditions" }\end{array}$ & $\begin{array}{l}\text { - Application of production line } \\
\text { balancing; } \\
\text { - Redefinition of the layout; } \\
\text { - Introduction of poka-yoke mechanisms } \\
\text { at the workplaces; } \\
\text { - Labour gymnastics. }\end{array}$ & $\begin{array}{l}\text { - Production takt time; } \\
\text { - Labour absenteeism rate due to } \\
\text { professional diseases; } \\
\text { - Number of conforming manufactured } \\
\text { products. }\end{array}$ \\
\hline P31 & $\begin{array}{l}\text { Propose improvements } \\
\text { of "workplace" }\end{array}$ & $\begin{array}{l}\text { - Application of } 5 S \text { to the workplaces; } \\
\text { - Redefinition of the layout; } \\
\text { - Time measurement; } \\
\text { - Application of REBA method. }\end{array}$ & $\begin{array}{l}\text { - Distances travelled by the workers; } \\
\text { - Time measurement in transport tasks; } \\
\text { - Number of MSD occurrences. }\end{array}$ \\
\hline P36 & $\begin{array}{l}\text { Propose"working } \\
\text { conditions" improvement } \\
\text { and load handling }\end{array}$ & $\begin{array}{l}\text { - Visual Management; } \\
\text { - Application of } 5 S \text { to the workplaces; } \\
\text { - Redefinition of the layout. }\end{array}$ & $\begin{array}{l}\text { - Distances travelled by the workers; } \\
\text { - Time measurement in transport tasks; } \\
\text { - Handling load measuring. }\end{array}$ \\
\hline
\end{tabular}




\subsection{Lean tools employed versus ergonomic factors and benefits of each tool}

After checking which ergonomic factors were present in each project, an analysis was conducted to verify which lean tool allowed risk reduction or improvement of the ergonomic factors. This analysis intended to answer the question "With which lean tools were ergonomic factors revealed and addressed?" (sQR13).

The deep relationship between the application of lean tools and the consequent improvement of the workplace and additional ergonomic factors was studied. Table 6 presents the lean tools applied in each project and its relation to ergonomic factors. Five lean tools were associated with a greater number of ergonomic factors, namely, 5S, standard work, visual management, Single Minute Exchange of Dies (SMED), and poka-yoke mechanisms.

Of these tools, 5S [56-58] was the most frequently used tool in the projects (with ten ergonomic factors). However, this frequency is not a new finding, since 5S was already recognised as a good tool to achieve an organised, clean, and standardised workplace in order to create a healthy environment and promote greater productivity. This tool is often seen as a basic starting point for LP implementation. The 5S method is a way to establish safety in the workplace based on the following five concepts: sort, set in order, shine, standardise, and sustain. It is relatively easy to understand and implement by training employees. It includes standardised procedures to prevent and detect safety gaps, as well as to improve employee adaptive interfaces to meet the ergonomic needs of interchangeable workers. Therefore, this tool is normally referred as $6 \mathrm{~S}$ by some authors due to also including the safety concept [59]. For example, there were several productive sections in companies where employees used chemicals substances when performing various operations. The manipulation of these substances can be quite harmful to the workers' health. Thus, individual protection measures, as well as upgraded machines, are unaccountable factors for the welfare of both the industrial environment and the employees. Therefore, proposals to improve the working conditions of employees are expected in a preventive manner. In most cases, improving the production sections allows solving a few problems related to low productivity, high lead time, absenteeism, and long distances between the workplaces. The implementation of the 5S philosophy depicted measures to increase productivity, promote the benefits of communication between managers and employees, and encourage improvements in ergonomics, safety, hygiene, and health at work.

The 5S tool can potentially address all the identified ergonomic factors because a careful management of the workplace and of the organisation of workstations is halfway to achieving all factors. Sometimes, students experimented the work conditions of workers by performing (simulating) their job in order to understand the quality of working conditions. Nevertheless, the project analysis made by the students does not seem to recognise all factors.

Standard work $[60,61]$ is an approach to LP that involves carefully documenting and regularly improving procedures. Standard work procedures should be routinely updated to eliminate waste. When a process is improved, it should consequently become safer. Also, unnecessary movements or motions (such as reaching for tools or bending to pick up heavy objects) increase the risk of injury. Improving workstation ergonomics reduces such risks, reduces unnecessary movements, and sustains a more efficient workflow. Many examples can be found in P18 [62] and P32.

Table 6. Lean tools versus ergonomic factors of lean-related projects

\begin{tabular}{|l|c|c|c|c|c|c|c|c|c|c|c|c|c|c|c|}
\hline Tools $x$ Factors & F5 & F1 & F9 & F2 & F12 & F3 & F4 & F6 & F11 & F7 & F8 & F10 & F13 & F14 & $\Sigma$ \\
\hline 5S & & & & & & & & & & & & & & & 10 \\
\hline Standard work & & & & & & & & & & & & & & & 9 \\
\hline Visual management & & & & & & & & & & & & & & 6 \\
\hline SMED & & & & & & & & & & & & & & 6 \\
\hline Poka-yoke & & & & & & & & & & & & & & 4 \\
\hline TPM & & & & & & & & & & & & & & & 2 \\
\hline Autonomation (jidoka) & & & & & & & & & & & & & & 2 \\
\hline Matrix skills & & & & & & & & & & & & & & 1 \\
\hline Six Sigma & & & & & & & & & & & & & & & 1 \\
\hline Kanban & & & & & & & & & & & & & & & 1 \\
\hline Kaizen & & & & & & & & & & & & & & & 1 \\
\hline Matrix training & 7 & 6 & 6 & 4 & 4 & 3 & 3 & 3 & 3 & 3 & 2 & 1 & 1 & 0 & 46 \\
\hline Heijunka & & & & & & & & & & & & & & & \\
\hline$\Sigma$
\end{tabular}


The main ergonomic aspects delivered and the benefits obtained concerning visual management are as follows: easy identification of problems; more satisfaction; easy identification of skills; key performance available to all; and awareness of what is happening by everyone. These aspects promote better communication and continuous improvement (kaizen) actions.

Safety may be integrated into kaizen methodologies [63] by analysing each operation of the process to find ways to reduce risks. The approach of kaizen measures with safety in mind combines the goals of process improvement and process safety. The application of kaizen methodology, besides reducing existent wastes, improves the reduction of the high value of overtime. Also, the involvement of people in continuous improvement leads to learning organisation [43] and business sustainability, as in the case of P36 [64].

SMED [65] is a tool to reduce the set-up time. It is also another tool very favourable to ergonomic efforts because it means fewer products near machines (fewer accidents and confusion; less stress because workers know what to do; tools with better ergonomic design; and quick changeover without compromising safety). As an example, this tool was successfully applied in P16 conducted in C10 [53, 66, 67].

Poka-yoke mechanisms $[68,69]$ are aimed to detect and avoid errors and are included in the Jidoka pillar of TPS [56]. The ergonomic aspects and benefits comprised are related with: people involvement; more responsibility and autonomy; more work control and motivation; use of colours to alert danger and/or prevent errors; fewer defects; and fewer machine breakdowns. P7 [70] and P18 [62] explore these mechanisms.

The previously described tools and the other tools presented in Table 5 are only a few examples of lean tools that benefit ergonomic work conditions in companies. A more integrated approach to improving the whole production system could be its total or partial reconfiguration. This approach was applied in many of the reported projects, namely, P2, P7, P8, P15, P9, P26, $\mathrm{P} 27$, and P35. The benefits achieved by these projects can be found in the literature [50], as well as the causeeffect relationship of working in a lean cell layout [10, 71]. Nevertheless, the decision to redesign production systems is not always straightforward and easy [72].

\subsection{Benefits of considering an ergonomic approach in a lean implementation}

LP implementation, when correctly performed, requires the effective analysis of ergonomic factors because ergonomics is an essential part of any sustainable organisation. The successful implementation of lean and ergonomics frequently includes redesigning the work, standardising the work process, and reducing or even eliminating the risk factors for musculoskeletal diseases. The outcome of the developed projects showed that LP tools reduce wastes, increase productivity, and, simultaneously, optimise the working conditions and improve employees' health [73].
A few conclusions were obtained from the analysed projects, and will now be described. Even when ergonomic parameters are not a primary concern in the development of the work plan, they end up being directly or indirectly contemplated. This outcome occurs mainly due to the relationship between ergonomics and the improvement of quality work conditions and production. Most of the analysed projects led to the conclusion that the implementation of lean-related projects allows:

A reduction of distances travelled by the workers, as well as, the reduction of movements;

A reduction of time spent in transport tasks;

Higher adequacy of the conditions at the workspaces;

Reduction of movements and physical effort in handling tasks during the work shifts;

Ergonomics involves both the productivity and human aspect, and one of its main goals is to increase the overall efficiency by improving the interaction between humans and the other parts of the work system. Tortorella et al. (2017) considered that for the lean manufacturing approach the Human element is a fundamental factor for the continuous improvement sustainability. For the same authors, from a lean perspective, ergonomics improves productivity, removes barriers to quality, and enhances safety for human activities [74].

The implementation of lean tools usually identifies lowcost solutions that yield substantial benefits. These benefits lead to increased safety in workplaces, reduced injuries, increased productivity, and increased the quality of the products.

The results obtained by [75] justify what was mentioned before, since they have been able to prove in their case study that it is possible to reduce the setup time (improving the productivity) and improve ergonomic conditions at the same time. These authors implemented improvements in the workstations, which simultaneously allowed to reduce the risk of MSD and the setup times. The reduced overburden (Muri) for workers and the avoided irregularity (Mura) that generates wrong interpretations, confusion, and stress are also benefits achieved with the main goal of lean: reducing waste or its symptoms. These valuable results are obtained through improvements in the interaction between the worker, machine, and workplace.

Nevertheless, much more could be achieved in the developed projects if a systematic questioning process was used. According to Maia et al. [34], not many methodologies to implement lean include ergonomic tools. Thus, a methodology that begins with the assessment of work conditions has been proposed [76, 77]. If this consideration is thought from the beginning, it could contribute to a better assessment of the work environment related to workplace-specific needs, allowing a more structured intervention [78]. This methodology was applied to some case studies and the results were very positive $[47,79]$. 


\section{CONCLUSIONS}

This paper intended to expose the symbiotic relationship between LP and ergonomics, based on the analysis of final-year projects reported in the master's dissertations in Industrial Engineering. The lean-related projects were developed in Production Systems Design and Operation, LP and Logistics research fields. However, projects revealed that the causes of many problems were related to ergonomic aspects, which were then assessed by ergonomic tools. Also, very often, these problems were not envisioned as being related to ergonomics and, thus, the objectives of the project did not contemplate an ergonomic assessment. At first sight, this could be seen as a limitation; however, it could provide an indication that the ergonomics concerns naturally emerge when lean-related projects are implemented.

After a critical analysis of the current situation using ergonomic tools, among others, solutions for the problems were lean tools such as 5S, visual management, and SMED, as was initially proposed. These solutions bring many tangible benefits, as well as intangible benefits, for the companies and their coworkers, since lean and ergonomics share similar concerns about their welfare.

Of the 41 projects developed in a total of 29 different companies, $78 \%$ addressed ergonomic factors. This percentage could probably be higher if ergonomic factors were reported in a systematic way. Another important aspect is that even projects did not consider ergonomic aspects in their initial phase, felt the need to use them at a later stage.

Also, some proposals were not implemented and, consequently, benefits were not measured. Additionally, because of the short time-span spent in the companies (mostly, and no more than, six months), some benefits were not achieved. However, it is important to notice that many benefits could be obtained with a systematic lean methodology addressing all relevant ergonomic aspects in a previous phase of lean implementation. Most of the analysed projects led to the conclusion that the implementation of lean-related projects allows (1) a reduction of distances travelled by the workers; (2) a reduction of time spent in transport tasks; (3) higher adequacy of the conditions at the workspaces; (4) reduction of movements and physical effort in handling tasks. Taking these factors into consideration, companies became more prepared for a real lean journey.

The master's dissertations interpretation by the paper co-authors is somehow a subjective approach due to the difficulties in identifying which ergonomic factors were considered. However, the lean tools considered by students were easly identified. Even though the 41 final projects were supervised, by at least one of the coauthors, there was much autonomous work performed by the students reported in their master's dissertations. Also, these projects correspond to the publication of the results obtained, in a written document, at the end of an internship. For the engineering students, this corresponds to the first opportunity to apply all the engineering knowledge learned. In further studies, it will be important to work in the referred methodology and use this in companies that want to implement lean.

\section{ACKNOWLEDGEMENTS}

The authors are grateful for the support provided by Fundação para a Ciência e Tecnologia (FCT) under the Strategic Project PEst2015-2020, with the reference Scope UID/CEC/00319/2019 (ALGORITMI).

\section{REFERENCES}

[1] Womack, J.; Jones, D.; Roos, D. (1990). The Machine That Changed the World: The Story of Lean Production, Free Press

[2] Bhamu, J.; Singh Sangwan, K. (2014). Lean manufacturing: literature review and research issues, International Journal of Operations \& Production Management, Vol. 34, No. 7, 876940. doi:10.1108/IJOPM-08-2012-0315

[3] Alves, A. C.; Kahlen, F.; Flumerfelt, S.; Siriban-Manalang, A.B. (2014). Lean Production Multidisciplinary: From Operations To Education, 7th International Conference on Production Research - Americas. doi:10.13140/2.1.1524.0005

[4] Amaro, P.; Alves, A. C.; Sousa, R. M. (2019). Lean Thinking: A Transversal and Global Management Philosophy to Achieve Sustainability Benefits, Lean Engineering for Global Development, Springer International Publishing, Cham, 1-31. doi:10.1007/978-3-030-13515-7_1

[5] Krafcik, J. F. (1988). Triumph of the Lean Production System, Sloan Management Review, Vol. 30, No. 1, 41-52

[6] Ohno, T. (1988). Toyota Production System: Beyond LargeScale Production

[7] Monden, Y. (1998). Toyota Production System: An Integrated Approach to Just-In-Time (Third Edit.), Engineering and Management Press

[8] Genaidy, A.; Karwowski, W.; Christensen, D. (1999). Principles of work system performance optimization: A business ergonomics approach, Human Factors and Ergonomics in Manufacturing, Vol. 9, No. 1, 105-128. doi:10.1002/(SICI)1520-6564(199924)9:1<105::AIDHFM6>3.0.CO;2-S

[9] Sugimori, Y.; Kusunoki, K.; Cho, F.; Uchikawa, S. (1977). Toyota production system and Kanban system Materialization of just-in-time and respect-for-human system, International Journal of Production Research, Vol. 15, No. 6, 553-564. doi:10.1080/00207547708943149

[10] Arezes, P. M.; Dinis-Carvalho, J.; Alves, A. C. (2015, August 19). Workplace ergonomics in lean production environments: A literature review, Work, IOS Press, 57-70. doi:10.3233/WOR-141941

[11] Paez, O.; Dewees, J.; Genaidy, A.; Tuncel, S.; Karwowski, W.; Zurada, J. (2004). The lean manufacturing enterprise: An emerging sociotechnological system integration, Human Factors and Ergonomics in Manufacturing, Vol. 14, No. 3, 285-306. doi:10.1002/hfm.10067

[12] Dul, J.; Neumann, W. P. (2009). Ergonomics contributions to company strategies, Applied Ergonomics, Vol. 40, No. 4, 745752. doi:10.1016/j.apergo.2008.07.001

[13] Bhasin, S.; Burcher, P. (2006). Lean viewed as a philosophy, Journal of Manufacturing Technology Management, Vol. 17, No. 1, 56-72. doi:10.1108/17410380610639506

[14] Canada, N. R. C. (2004). Principles of Lean Thinking - Tools \& Techniques for Advanced Manufacturing

[15] Abdullah, F. (2003). Lean Manufacturing tools and techniques in the process industry with a focus on stee/University of Pittsburgh

[16] Shingo, S. (1989). A Study of the Toyota Production System from an Industrial Engineering Viewpoint (Revised Ed.), Productivity Press, Cambridge, Massachusetts and Norwalk, Connecticut

[17] Melton, T. (2005). The Benefits of Lean Manufacturing, 
Chemical Engineering Research and Design, Vol. 83, No. 6, 662-673. doi:10.1205/cherd.04351

[18] Womack, J. P.; Jones, D. T. (1996). Lean Thinking: Banish Waste and Create Wealth in Your Corporation, (F. Press, Ed.), Free Press, New York

[19] Womack, J. P.; Jones, D. T. (1994). From Lean Production to the Lean Enterprise, Harvard Business Review, Vol. 72, No. 2 , 93-103 doi:http://search.ebscohost.com/login.aspx?direct=true $\& \mathrm{db}=$ buh\&AN=9405100922\&site=ehost-live

[20] Hines, P.; Found, P.; Griffiths, G.; Harrison, R. (2011). Staying Lean, Productivity Press. doi:10.1201/b10492

[21] IEA- International Ergonomics Association. (2016) Ergonomics human centered design, Definition and Domains of Ergonomics, 1, from http://www.iea.cc/whats/, accessed 17-1-2016

[22] Nunes, I. L. (2015). Integration of Ergonomics and Lean Six Sigma. A Model Proposal, Procedia Manufacturing, Vol. 3 No. Ahfe, 890-897. doi:10.1016/j.promfg.2015.07.124

[23] David, G. C. (2005). Ergonomic methods for assessing exposure to risk factors for work-related musculoskeletal disorders, Occupational Medicine, Vol. 55, No. 3, 190-199. doi:10.1093/occmed/kqi082

[24] Chiasson, M.-È.; Imbeau, D.; Major, J.; Aubry, K.; Delisle, A (2015). Influence of musculoskeletal pain on workers' ergonomic risk-factor assessments, Applied Ergonomics, Vol. 49, 1-7

[25] Kee, D.; Karwowski, W. (2007). A Comparison of Three Observational Techniques for Assessing Postural Loads in Industry, International Journal of Occupational Safety and Ergonomics (JOSE), Vol. 13, No. 1, 3-14 doi:10.1080/10803548.2007.11076704

[26] Madani, D. Al; Dababneh, A. (2016). Rapid Entire Body Assessment: A Literature Review, American Journal of Engineering and Applied Sciences, Vol. 9(1), No. Literature Reviews Rapid, 107-118. doi:10.3844/ajeassp.2016.107.118 Julie, J.; Ji, Y.; Francois, S.; McClellan, M. (2012). Human Factors and Ergonomic Methods, G. Salvendy (Ed.) Handbook of Human Factors and Ergonomics (Fourth Edi.), John Wiley \& Sons, Inc., New Jersey, 274-295

[28] Ahonen, M.; Launis, M.; Kuorinka, T. (1989). Ergonomic Workplace Analysis

[29] Shoaf, C.; Genaidy, A.; Karwowski, W.; Waters, T.; Christensen, D. (1997). Comprehensive manual handling limits for lowering, pushing, pulling and carrying activities, Ergonomics, Vol. 40, No. 11, 1183-1200. doi:10.1080/001401397187432

[30] Genaidy, A. M.; Karwowski, W. (2003). Human performance in lean production environment: Critical assessment and research framework, Human Factors and Ergonomics in Manufacturing, Vol. 13, No. 4, 317-330. doi:10.1002/hfm. 10047

[31] Dul, J.; Neumann, W. P. (2009). Ergonomics contributions to company strategies, Applied Ergonomics, Vol. 40, No. 4, 745752. doi:10.1016/j.apergo.2008.07.001

[32] Genaidy, A. M.; Karwowski, W. (2003). Human performance in lean production environment: Critical assessment and research framework, Human Factors and Ergonomics in Manufacturing, Vol. 13, No. 4, 317-330. doi:10.1002/hfm.10047

[33] Brito, M. F.; Ramos, A. L. F. A.; Carneiro, P.; Gonçalves, M. A.; Ferreira, J. A. de V.; Frade, A. B. T. (2018). Improving the Production Performance and Ergonomic Aspects Using Lean and Agile Concepts. The Open Cybernetics \& Systemics Journal, Vol. 12, No. 1, 122-135. doi:10.2174/1874110X01812010122

[34] Maia, L. C.; Alves, A. C.; Leão, C. P. (2012). Do Lean Methodologies include ergonomic tools?, Proceedings of International Symposium on Occupational Safety and Hygiene (SHO2012), 350-356

[35] Melton, T. (2005). The Benefits of Lean Manufacturing: What Lean Thinking has to Offer the Process Industries, Chemical Engineering Research and Design, Vol. 83, No. 6, 662-673. doi:10.1205/cherd.04351

[36] Da, S.; Vieira, S.; Badke-schaub, P.; Fernandes, A. (2015). ScienceDirect Framework of Awareness: for the analysis of Ergonomics in Design, Procedia Manufacturing, Vol. 00, No. Ahfe, 729-736. doi:10.1016/j.promfg.2015.07.688
[37] Guimarães, L. B. D. M.; Anzanello, M. J.; Ribeiro, J. L. D. Saurin, T. A. (2015). Participatory ergonomics intervention for improving human and production outcomes of a Brazilian furniture company, International Journal of Industrial Ergonomics, Vol. 49, 97-107. doi:10.1016/j.ergon.2015.02.002

[38] Poggio, T.; Beymer, D. (1996). Learning to see, IEEE Spectrum, Vol. 33, No. 5, 60-69. doi:10.1109/6.490058

[39] Santos, Z. G. dos; Vieira, L.; Balbinotti, G. (2015). Lean Manufacturing and Ergonomic Working Conditions in the Automotive Industry, Procedia Manufacturing, Vol. 3, No. Ahfe, 5947-5954. doi:10.1016/j.promfg.2015.07.687

[40] Losonci, D.; Demeter, K.; Jenei, I. (2011). Factors influencing employee perceptions in lean transformations, International Journal of Production Economics, Vol. 131, No. 1, 30-43. doi:10.1016/j.ijpe.2010.12.022

[41] Joseph, B. S. (2003). Corporate ergonomics programme at Ford Motor Company, Applied Ergonomics, Vol. 34, No. 1, 23-28. doi:10.1016/S0003-6870(02)00080-7

[42] Moody, L. (2012). Human Factors and Lean in the ER: A Review of the Literature, Proceedings of the 2012 Symposium on Human Factors and Ergonomics in Health Care, Human Factors and Ergonomics Society, 20-26. doi:10.1518/HCS2012.945289401.004

[43] Alves, A. C.; Dinis-Carvalho, J.; Sousa, R. M. (2012, April 13). Lean production as promoter of thinkers to achieve companies' agility, (G. D. Putnik, Ed.)Learning Organization, 219-237. doi:10.1108/09696471211219930

[44] Ghosh, S.; Young-Corbett, D. (2009). Intersection between lean construction and safety research: a review of the literature, Proceedings of the 2009 Industrial Engineering Research Conference

[45] Oliveira, B.; Alves, A.; Carneiro, P.; Ferreira, A. C. (2017). Integration of Ergonomics and Lean Production to improve productivity and working conditions, G. P. (eds. . Arezes, P., Baptista, J.S., Barroso, M.P., Carneiro, P., Cordeiro, P., Costa, N., Melo, R., Miguel, A.S., Perestrelo (Ed.), Occupational Safety and Hygiene - SHO2017, Guimarães, 107-109

[46] Maia, L. C.; Eira, R.; Alves, A. C.; Leão, C. P. (2015). A melhoria organizacional como alavanca para melhores condições de trabalho, RISTI - Revista Iberica de Sistemas e Tecnologias de Informacao, No. E4, 50-65. doi:10.17013/risti.e4.50-65

[47] Eira, R.; Maia, L. C.; Alves, A. C.; Leão, C. L. (2015). Ergonomic intervention in a Portuguese Textile Company to achieve Lean principles, P. Arezes; J. Baptista; M. Barroso; P. Carneiro; P. Cordeiro; N. Costa; R. Melo; A. Miguel; G. Perestrelo (Eds.), SHO2015: International Symposium on Occupational Safety and Hygiene, PORTUGUESE SOC OCCUPATIONAL SAFETY \& HYGIENE, Guimarães, Portugal, 100-102

[48] Hsieh, H.-F.; Shannon, S. E. (2005). Three Approaches to Qualitative Content Analysis, Qualitative Health Research, Vol. 15, No. 9, 1277-1288. doi:10.1177/1049732305276687

[49] Bhat, S. (2008). Cellular manufacturing - the heart of Lean Manufacturing, Advances in Production Engineering \& Management, Vol. 3, 171-180

[50] Alves, A.; Sousa, R.; Dinis-Carvalho, J.; Moreira, F. (2015). Production systems redesign in a lean context: $A$ matter of sustainability, FME Transaction, Vol. 43, No. 4, 344-352. doi:10.5937/fmet1504344A

[51] Dinis-Carvalho, J.; Alves, A. C.; Sousa, R. M. (2014). Moving from job-shop to production cells without losing flexibility: A case study from the wooden frames industry, South African Journal of Industrial Engineering, Vol. 25, No. 3, 212-225

[52] Bragança, S.; Alves, A.; Costa, E.; Sousa, R. (2013). The use of lean tools to improve the performance of an elevators company, Integrity, Reliability and Failure of Mechanical Systems (IRF2013) (Vol. 1), 1-8

[53] Costa, E.; Braganca, S.; Alves, A.; Sousa, R. (2014). Actionresearch methodology to improve performance using lean production tools, Technics Technologies Education Management, Vol. 9, No. 2, 253-264

[54] Queta, V.; Alves, A. C.; Costa, N. (2014). Project of ergonomic shelves for supermarkets in a Lean work environment, International Symposium on Occupational Safety and Hygiene 
[55] Vicente, S.; Alves, A. C.; Carvalho, S.; Costa, N. (2016). Improving Safety and Health in a Lean Logistic project: a case study in an automotive electronic components company, $\mathrm{P}$. Arezes; J. Baptista; M. Barroso; P. Carneiro; P. Cordeiro; N. Costa; R. Melo; A. Miguel; G. Perestrelo (Eds.), SHO2015: International Symposium on Occupational Safety and Hygiene, PORTUGUESE SOC OCCUPATIONAL SAFETY \& HYGIENE

[56] Monden, Y. (1983). Toyota Production System - An Integrated Approach to Just-in-Time (First Edit.), Institute Industrial Engineers

[57] Osada, T. (1991). The 5S's: Five Keys to a Total Quality Environment, Tokyo: Asian Productivity Organisation.

[58] Bidarra, T.; Godina, R.; Matias, J. C. O.; Azevedo, S. G. (2018). SMED Methodology Implementation in an Automotive Industry Using a Case Study Method, International Journal of Industrial Engineering and Management (IJIEM), Vol. 9, No. June, $1-16$

[59] The Productivity Press Development Team. (1996). 5S for Operators, Portland: Productivity Press

[60] The Productivity Press Development Team. (2002). Standard Work for the Shopfloor, Productivity Press, New York

[61] Williams, B. A. (2001). Standard Work - Lean Tools and Techniques, SAE Technical Paper. doi:10.4271/2001-012598

[62] Ribeiro, L.; Alves, A. C.; Moreira, J. F. P.; Ferreira, M. (2013). Applying Standard Work in a paint shop of a wood furniture plant: a case study, 22nd International Conference on Production Research

[63] Imai, M. (1991). Kaizen. The Key to Japan's Competitive Sucess, Random House, New York

[64] Vicente, S.; Alves, A. C.; Carvalho, S.; Costa, N. (2015). Business sustainability through employees involvement: a case study, FME Transactions, 1-8

[65] Shingo, S. (1985). A Revolution in Manufacturing: The SMED System, Productivity Press

[66] Costa, E.; Bragança, S.; Sousa, R.; Alves, A. (2013). Benefits from a SMED Application in a Punching Machine, World Academy of Science, Engineering and Technology, Vol. 7, No. 5, 379-385

[67] Costa, E. S. M. da; Sousa, R. M.; Bragança, S.; Alves, A. C. (2013). An industrial application of the SMED methodology and other lean production tools, 4th International Conference on Integrity, Reliability and Failure, 1-8

[68] Pojasek, R. B. (1999). Poka-Yoke and Zero Waste, 91-98

[69] Blackt, J. (2007). Design rules for implementing the Toyota Production System, International Journal of Production Research, Vol. 45, No. 16, 3639-3664. doi:10.1080/00207540701223469

[70] Carvalho, R.; Alves, A.; Lopes, I. (2011). Principles and practices of lean production applied in a metal structures production system, Proceedings of the World Congress on Engineering 2011, WCE 2011 (Vol. 1), 744-749

[71] Arezes, P. M.; Dinis-Carvalho, J.; Alves, A. C. (2010). Threats and Opportunities for Workplace Ergonomics in Lean Environments, 17th International Annual EurOMA Conference -Managing Operations in Service Economics, 10

[72] Alves, A. C.; Sousa, R. M.; Dinis-Carvalho, J. (2015). Redesign of the production system: A hard decision-making process, 2015 IEEE International Conference on Industrial Engineering and Engineering Management (IEEM) (Vol. 2016-Janua), IEEE, 1128-1132. doi:10.1109/IEEM.2015.7385824

[73] Saurin, T. A.; Ferreira, C. F. (2009). The impacts of lean production on working conditions: A case study of a harvester assembly line in Brazil, International Journal of Industrial Ergonomics, Vol. 39, No. 2, 403-412. doi:10.1016/j.ergon.2008.08.003

[74] Tortorella, G. L.; Vergara, L. G. L.; Ferreira, E. P. (2017). Lean manufacturing implementation: an assessment method with regards to socio-technical and ergonomics practices adoption, The International Journal of Advanced Manufacturing Technology, Vol. 89, Nos. 9-12, 3407-3418. doi:10.1007/s00170-016-9227-7

[75] Brito, M.; Ramos, A. L.; Carneiro, P.; Gonçalves, M. A. (2017). Combining SMED methodology and ergonomics for reduction of setup in a International turning and production area, Procedia Manufacturing, Vol. 13, No. 13, 1112-1119. doi:10.1016/j.promfg.2017.09.172

[76] Maia, L. C.; Alves, A. C.; Leão, C. P. (2012). Design of a Lean Methodology for an Ergonomic and Sustainable Work Environment in Textile and Garment Industry, Volume 3: Design, Materials and Manufacturing, Parts $A, B$, and $C$ (Vol. 3), ASME, 1843. doi:10.1115/IMECE2012-89048

[77] Maia, L. C.; Alves, A. C.; Leão, C. P. (2013). Sustainable Work Environment with Lean Production in Textile and Clothing Industry, International Journal of Industrial Engineering and Management (IJIEM), Vol. 4, No. 3, 183-190

[78] Tuncel, S.; Genaidy, A.; Shell, R.; Salem, S.; Karwowski, W.; Darwish, M.; Noel, F.; Singh, D. (2008). Research to practice: Effectiveness of controlled workplace interventions to reduce musculoskeletal disorders in the manufacturing environment-critical appraisal and meta-analysis, Human Factors and Ergonomics in Manufacturing, Vol. 18, No. 2, 93124. doi:10.1002/hfm.20104

[79] Maia, L. C.; Alves, A. C.; Leão, C. P.; Eira, R. (2017). Validation of a methodology to implement Lean Production in Textile and Clothing Industry, ASME International Mechanical Engineering Congress and Exposition, Proceedings (IMECE) (Vol. 2). doi:10.1115/IMECE2017-71464 